\title{
17
}

\section{Australian Photographic Histories After Colonialism}

\author{
JANE LYDON
}

In 1788 the British established a penal settlement at Sydney Cove, New South Wales, on the traditional country of the Darug, Dharawal and Gundungurra language groups (Attenbrow 2002: xiii). At this time more than 200 languages were spoken across the continent, representing distinct 'nations' (Dixon 2011). The motives of the British centred upon the need for a new colony following the loss of her American colonies, with all the strategic, economic and social advantages of this prosthetic state (e.g. Coleman 2005). Although many white settlers acknowledged the prior occupation of Indigenous people, from the mid-1830s the notion that the land belonged to no one before the British Crown took it provided the legal and popular basis for dispossession of Aboriginal Australians. ${ }^{1}$ Assumptions about the value of using and exploiting nature underpinned these natural law ideas of property, and fundamental to this process was the conquest and control of other peoples' lands and goods. The legal origins of these ideas lie in the Roman Institutes of Justinian, the sixth century codification of Roman law ordered by the Byzantine Emperor, that stated, for what previously belonged to no one is, by natural reason, accorded to its first taker [quod enim ante nullius est id naturali ratione occupanti conceditur] (Fitzmaurice 2007: 6-7). This Roman 'law of the first taker' was subsequently reified within Western law, and used in debates regarding property and the rights of colonized peoples from the sixteenth century onwards. The law of the first taker' also provides an apt metaphor for the principle underlying subsequent Australian 
histories of photography, that were until the late twentieth century structured by the celebration of 'firsts': first photographer to travel to Australia from the metropole, first recorded view of each 'new' place, first sight of the Indigenous people and so forth. As numerous scholars have shown (e.g., Ryan 2007, Morris 2009, Hartmann et al 1998, Edwards 1992, Berkhofer 1978), photography's dissemination and application was broadly concurrent with the expansion of European imperialism, and the medium played a key role in this imaginative geography of Empire, articulating a range of imperial ideologies.

In the twenty-first century, no account of photography in Australia can overlook the fundamental significance of the nation's status as a former settler colony: as photography historian Helen Ennis (2007: 8) argues, for example, what is distinctive about the Australian photographic record is its origins within imperialism and modernity, and therefore relations between white settlers and Indigenous people have profoundly shaped the visual archive. In Australia, as elsewhere, postcolonial scholarship developed from the political activism of post-World War II anti-colonial liberation movements, allied to the intellectual critique of the structures of colonialism, aiming to demonstrate the reliance of Western systems of thought upon the colonial other (e.g. Fanon 1961). Postcolonial scholarship has revealed the disjunction between the apparent progressivism and benevolence of the universals of the European Enlightenment tradition - such as historicism, reason, and humanism - and their restricted deployment in colonial practice, where they were reduced to the figure of the White settler male (Chakrabarty 2000). In temporal terms, 'post-colonial' therefore pertains to a distinct period in world history, namely the aftermath of European imperialism post-World War II. However, while these great world systems have been dismantled, various disguised forms of colonialism and neo-colonialism continue to flourish. Here I use the term primarily to refer to a specific theoretical approach rather than denoting a temporal period, because it cannot be argued that we have left colonialism behind. While colonialism has often been evoked as a global and transhistorical logic rather than a practically mediated relation (Thomas 1994: 3), I seek to place these diverse processes in historical and global context. Across the vast Australian continent, the historically specific circumstances of each former colony and its changing relations with local Indigenous peoples, and their intersection with developing photographic technologies, largely determined what was photographed and how (Lydon 2014b).

Crucially, postcolonial scholarship has revealed the importance of representation in securing the West's dominance over the colonized. Drawing upon philosopher Michel Foucault's arguments for the mutual constitution of knowledge and power through discourse, and for the role of classification in differentiating and governing populations, Edward Said's (1978) Orientalism 
demonstrated how management of the peoples of the Middle East was effected through a Western discourse of orientalism organized through such academic disciplines as anthropology, archaeology, and history. Said showed that Western conceptions of history and culture, and the devices we use to conceive, construct and convey meaning about other peoples, are profoundly implicated in imperialism and oppression. During the 1980s these insights were developed within postcolonial scholarship through a central concern with representation and the analysis of the ways that Western powers wrote about, depicted and administered the colonized. In an influential approach drawn from semiotics and psychoanalysis, Homi Bhabha (2004: 153) has argued for the 'ambivalence of colonial rule', suggesting that "the colonial presence is always ambivalent, split between its appearance as original and authoritative and its articulation as repetition and difference'. Postcolonial scholarship's emphasis on discourse and language has been extended by cultural theorists, following Pierre Bourdieu, to embrace 'a pluralized field of colonial narratives, which are seen less as signs than as practices, or as signifying practices rather than elements of a code' (Thomas 1994: 8).

A chief analytical tactic of postcolonial critique has been to identify and destabilize discursive strategies such as the stereotype and the construction of binaries: by demonstrating the interdependence of cultural and political formations, it has been possible to challenge oppositions between East/West, center/periphery, us/them, Black/White, and so undermine the basis for colonial inequalities. The call to consider 'metropole and colony within a single analytic field' (Cooper and Stoler 1997: 15) has revealed the impact of the empire back 'home' in Europe, and the ways that metropolitan ideas and practices were shaped by the colonial experience, as part of a connected, though structurally deeply unequal, history. Over the past two decades, the 'networks' and 'webs' of power, knowledge, opportunity and mobility which marked European imperialism have attracted intense scholarly attention, prompted by the recognition that explanations of historical processes are distorted by nationalist frameworks. The rise of transnational histories has demonstrated how metropole and colony were always linked by flows of people, goods, ideas, and technologies, including photography, and alongside this upsurge of interest in transnational circulations, an attention to networks and flows has highlighted such traffic across national/colonial/imperial borders.

The initial concern with bringing metropole and colony into a single framework has been enriched by conceptions of the empire as a set of shifting and uneven inter-regional and global connections, or 'webs' and the growing recognition of the significance of the situated colonial site in shaping or directing aspects of these networks (Hall 2002, Ballantyne 2012, Carey and Lydon 2014). We now recognize, for example, that the histories of humanitarianism and human rights 
entailed a process that developed dialogically between the Western metropole and the colonies during the nineteenth century, as debates about universal humanity were fought around race, slavery, colonialism and imperial rule (Skinner and Lester 2012, Barnett 2011).

Deborah Poole's (1997) exploration of 'visual economies' captures this sense of global networks, showing that the wide circulation of visual images and technologies played a crucial role in shaping modern understandings of race. Photographs became an increasingly important means of proving arguments, mobilizing audiences, sharing ideas and witnessing far-distant circumstances; but above all, they created relations between far-distant peoples, and prompted emotions such as compassion and empathy. In this way photography participated in debates regarding the diversity of humankind, the place of Indigenous peoples under imperial rule, and their rights to fair treatment. Photographs pictured a shared category of 'human' and allowed new ideas to emerge of a universal humanity, and a global political community (Lydon 2016).

As well as bringing colonial experience into conversation with metropolitan debates, scholars of photography have drawn upon a conception of colonialism as a series of cultural projects to situate colonial images and narratives in a specific time and place, revealing how localized subjectivities and photographic 'vernaculars' are constituted. Such research has demonstrated that while photography was long considered a European invention and medium, its multifarious uses for specific cultural and political purposes have produced diverse forms and visual practices in what may be seen as globally disseminated and locally appropriated forms (e.g. Pinney and Peterson 2003). For example, Stephen Sprague's classic study of Yoruba uses of photography reveals the incorporation of the medium into many traditional and contemporary aspects of their culture. In smaller West African settlements, especially, a distinctive synthesis of tradition, historical photographic and British practices have combined to produce a local genre of portrait-making (Sprague 1997). The photograph's recodability allows it to be transformed according to context: a distancing anthropometric record of an Indigenous prisoner produced during the 1870s, for example, may today be regarded as a family portrait, linking present-day Aboriginal communities with their ancestors, lost through the displacements of assimilation and dispossession. As Michael Aird's (2003) and Joanne Driessens' (2003) contributions to Photography's Other Histories explain, these earlier anthropological photographs are stored in the archive, buried 'like a vein of gold' for later recuperation by relatives (Pinney 2003: 4).

\section{THE LAW OF THE FIRST TAKER: TERRA NULLIUS?}


What was the photographic history of the 'first taker'? After photography was officially invented in 1839, practitioners of the new method quickly saw its commercial benefits and transported it around the globe. The first Australian daguerreotype made in April 1841 was a product of French entrepreneurship: now-lost, this image of a street beside Sydney's port was taken by Captain Augustin Lucas, of a French Naval School Expedition supported by the influential Paris Society to Encourage National Industry [la Société d' Encouragement pour l'Industrie Nationale] (Wood 2005). This speculative beginning was quickly followed by the arrival of adventurous photographers capitalising on curiosity about foreign sights and peoples, as well as local desires for domestic portraits. Photographers quickly saw the commercial value of taking photographs of Australian Aboriginal people. Ideas about them had been shaped by Western conceptions of progress and civilisation since first contact, many observers arguing that they represented an earlier stage of humankind (e.g. Cunningham 1827: 46).

As a result of the growing belief that the Aboriginal race was doomed to extinction, photographers sought to record what was believed to be a disappearing way of life. They followed the 'frontier', seeking Aboriginal people apparently untouched by change — seemingly 'primitive', 'authentic' subjects, stripped of signs of European civilisation (such as clothing). As colonisation spread, such people were harder to find, or paradoxically required greater intervention to appear untouched. Douglas Kilburn's daguerreotypes of the Kulin Nations people of southern-central Victoria recorded people visible on the streets of the growing town of Port Philip, now Melbourne, established only in 1835 .

Their frontal regard expresses the distance many viewers brought to this encounter, a view exaggerated by further dissemination of the portraits in engraved or painted form. William Westgarth's popular guide for prospective settlers Australia Felix (1848) was one of the first to include Kilburn's portraits. Westgarth, however, did not offer a favorable view of Indigenous Australians: as historian Jessie Mitchell notes, he was typical of accounts during this decade of rapid white settlement in emphasizing the colony's potential for colonists, but characterizing Aboriginal people as lazy, savage and doomed to extinction. One reviewer noted of Westgarth's discussion of Australian Indigenous people that it was 'a disagreeable subject, because so soon as our curiosity is gratified, every philanthropic hope is destroyed by the conviction, forced upon us by the failure of repeated attempts, that the race is incapable of elevation' (Anonymous 1848).

Yet although many accounts of colonial photography have emphasized the medium's controlling and destructive effects upon its Indigenous subjects, as we now understand such encounters entailed exchange as well as objectification. Rather than being passive victims, there is considerable evidence for historical interactions between photographer and Indigenous 
people and the ways that such images can be understood to express the process of cross-cultural exchange (Lydon 2014a). As Indigenous scholar Marcia Langton (1993: 39) argued more than twenty years ago, 'the problem' with analysis of the visual representation of 'Aborigines lies in the positioning of us as object, and the person behind the camera as subject'. During the 1850s, for example, Melbourne photographer Hubert Haselden used a series of daguerreotype portraits of Kulin people to advertise his 'Daguerrean \& Photographic Artists' establishment. Originating in the face-to-face studio encounter within the photographer's studio, these photographic objects assumed very different meanings as they circulated within and across diverse cultural domains: to satisfy white curiosity, as celebrity portraits, as self-representations and to embody family. As is often the case where daguerreotypes have disappeared, the only surviving portrait from this series comprises an engraving, based on a drawing by Nicholas Chevalier, based on Haselden's daguerreotype, of Wurundjeri leader Simon Wonga and his wife Maria (fig 17.1). ${ }^{2}$

The Illustrated Melbourne Post ('The Interesting Couple', 1862: 2) explained that Wonga had 'considerable claims on our notice', being 'the son of Jagga Jagga, the celebrated Port Phillip chief, and friend of Batman. The interesting couple will be readily recognised, not only by Melbournites, but by many through the surrounding districts, where Simon and his lubra [Aboriginal woman] pay their periodical visits'. Wonga, in particular, was a Wurundjeri leader but was also of considerable interest to European viewers. Wonga was equally interested in the results of photography as historian of science John Kean's (in prep) research has shown: in 1857 Wonga exchanged the nest and egg of a superb lyrebird, known by the Wurundjeri as the Bullan-Bullan, for two photographs - no doubt Haselden's daguerreotypes. The German artist, explorer and naturalist Ludwig Becker (1857: 153-54) told how:

I put myself in direct communication with him [Wonga] in order to obtain as much information as he could give from his own experience, concerning the native animals, etc. By presenting him and one of his relations with their respective photographic portraits, I succeeded at last in making them fulfill a long given promise, and accordingly they brought a nest and egg of the Menura Superba to Melbourne.

So while it is crucial not to dismiss the often enormous power inequalities that shaped colonial relations, photography does not tell us simply what 'the white photographer saw', nor was it inevitably a means of defining and managing Aboriginal subjects. Our understanding of these images is radically re-oriented when we ask: what were the views and experiences of the Indigenous participants? In contrast to research that defines colonial photography simply as the white 
photographer's view, it is possible to see how the camera frequently became a medium of exchange, and served a range of purposes within Indigenous and Western knowledge systems.

\section{DARWINISM AND PHOTOGRAPHY}

Following the publication of Charles Darwin's The origin of species by means of natural selection (1859), his theory of evolution quickly became scientific orthodoxy and such ideas only strengthened. While many theories regarding the diversity and alteration of living species across time had previously been advanced, evolutionism, as it is often called, explained the mechanism of transformation. Darwin argued that within any group of individuals, some will bear traits that are environmentally advantageous, and so more likely to promote the individual's survival, therefore passing on these traits to descendants. This gradual process of adaptation to the environment produced distinct and divergent descendant organisms. Applied to humankind, the social evolutionist paradigm was used to rationalize the ill effects of invasion and dispossession upon Indigenous people. The general public took a great interest in these theories and debates during the nineteenth century, and the market for images of Indigenous people comprised a large general audience, as well as scientists and collectors. With the emergence of the cheap, palm-sized carte de visite in the mid-1850s, portraiture became an international craze, allowing individual, group and familial portraiture across all classes, prompting an international trade in celebrities and permitting collectors to obtain examples, or 'types', of different peoples from around the world. Photographers recorded diverse Indigenous Australians in images that found their way into scientific collections across the globe. As Michael Aird (2014) has shown, during the 1860s many featured portraits from Queensland, which had been made a new colony in 1859. Local studios recorded people still leading a noticeably traditional way of life, posed in heavily staged tableaux in front of painted outdoor scenes. This intense activity resulted in collections such as thirteen cartes de visite held by the British Museum featuring individuals with known biographies such as Kirwallie Sandy, an Aboriginal man from the Brisbane region.

While officials sought to segregate Indigenous people in farming settlements, such places were also key sites of cultural encounter. In Victoria the six major missions and reserves established around 1860 became places of contact and exchange between black and white, and the visual record reflects this process, with sites such as Coranderrk, near Melbourne, generating thousands of photographs (Lydon 2005). The Indigenous residents quickly became aware of how they were being represented, and it was frequently noted of Coranderrk that they collected and treasured 
such portraits. Photographs, visitors reported, were widely owned and in 1876 one stated that 'some of the chief objects of desire' were 'photographic representations of their own and their children's countenances' (Anonymous 1876). The young Italian scientist Enrico Giglioli (1875: 773) described how 'the inside walls of [their homes] were in most cases papered with cuttings from English and Australian illustrated journals, and photographs, greatly prized by these people'.

However from the 1870 s onwards, evolutionist notions of Aboriginality began to predominate within the white settler population, as Darwinism became dogma, and a racial hierarchy was cemented in place. As control tightened in southern Australia over the last decades of the nineteenth century, greater distance between black and white was expressed through images of people living on government institutions, seemingly transformed. Northern and north-western Australia remained a 'frontier' and a source of 'authentic', 'primitive' views of tradition.

By the early twentieth century, however, cheap Kodak cameras started to become widely available, allowing Aboriginal people to adopt the medium for their own purposes. As a storekeeper on the remote desert Birdsville Track wrote to a friend in 1933, 'Nearly all the young [Aborigines] today go through a Kodak stage. I have three box Brownies left here for repairs by young [Aborigines] who have had the craze.' (Jones 2011: 48). Recent research has also begun to identify early Aboriginal photographers, such as Aunty Charlotte Richards, a prolific Ngarrindjeri photographer from the 1940s to the 1980s (Hughes and Trevorrow 2014). The Ngarrindjeri are a South Australian Aboriginal nation, comprising several peoples with a common language, whose land and waters (ruwe) take in the River Murray, lakes Alexandrina and Albert, the vast Coorong wetlands and the Southern Ocean coast. Born around 1930, Richards grew up in camps along the Riverland and Coorong, and lived for a considerable time at One Mile fringe camp, like many other Aboriginal people, excluded by official policy and popular prejudice from the region's towns. She was unusual in not having children to support, and used her income derived from sewing bags and picking fruit to pay for her photography, and to share the results among her kin. Her family remembers her love of camp life, especially fishing and rabbiting, and her strict care for her collection of photos, now a unique record of life beyond official surveillance, and constituting a familial, not government archive (Hughes and Trevorrow 2014) (fig 17.2).

From the 1930s, activists took up photography as a form of witness to past injustice and as the basis of demands for rights in the present (Lydon 2012). When the movement for Indigenous rights gained momentum during the 1970s, Indigenous and non-Indigenous photographers seized upon the medium as a means to express an explicitly Indigenous perspective; their political project was frequently driven by an intense desire to counter degrading historical imagery. Aboriginal people recognized that the visual archive offered evidence for their historical experience, and 
might be re-framed by Indigenous narratives in order to counter colonial, often documentarybased, history.

During the early 1980s, an Indigenous art photography movement began to emerge that began to represent Aboriginal culture, identity and political claims from an explicitly Aboriginal perspective. A range of young Aboriginal photographers emerged, including Tracey Moffatt, Brenda L Croft and Michael Riley. The Bicentennial year - marking 200 years of British settlement in 1988 -was a particularly important landmark that focused attention on the nation's unresolved past, and the present place of its Indigenous citizens. Indigenous photographers such as Southport-based Michael Aird recorded the wave of protest that countered the celebration of white settlement. His photo of Vincent Brady, now known as Qawanji Ngurku Jawiyabba, shows the Black Panther and son of radical Pastor Don Brady leading a Brisbane protest against Bicentennial celebrations (fig 17.3).

Such projects took issue with the celebration of the Bicentennial, rejecting the triumphalist tone of most commemoration. The Bicentennial also marked a fresh awareness of the significance of the past in demonstrating Aboriginal experience, including links to land and culture, and in explaining oppression in the present. New photographic analyses began to emerge at this time that acknowledged the nation's difficult and unresolved history, and the distinct perspective of Aboriginal people (Taylor 1988, Willis 1988). At this time, dominant theoretical approaches tended to emphasize photography's role in exploiting and distancing its Indigenous subjects (e.g. Tagg 1993, Solomon-Godeau 1991). These interpretations emerged in conjunction with poststructuralist critiques of modernism that emphasized the entanglement of knowledge, vision and power - and the medium's profound implication in structural inequalities of race, class and gender.

This interpretive tradition also shaped exhibitions of colonial Australian photography throughout the 1980s and 1990s, as historians of photography showed how ideas of primitivism had structured the ways that photos of Aboriginal people were circulated and viewed during the nineteenth century. However, in arguing that subaltern groups 'were represented as, and wishfully rendered, incapable of speaking, acting or organising for themselves', John Tagg (1993: 11) articulates a view of photographic meaning as wholly determined by norms, and of photographic subjects as passive victims. In such readings, the power relations inherent in colonialism have already decided the truth of these images. It is undeniable that the distancing effects of such images have evoked anger and grief from Indigenous people (e.g. Croft 1997), however, Aboriginal communities have also begun to draw upon the radical potential of the photographic archive to be re-worked and re-evaluated by Indigenous relatives and descendants of their subjects. 
For example, Lawrence Bamblett grew up in the Wiradjuri community of Erambie Mission at Cowra and completed a doctorate that explored cultural continuity through storytelling within his community. In the course of his research, he observed how photographs are an integral part of the community's oral history tradition and are used as memory aids - in recording sporting prowess for example. He notes the reluctance of some owners of photographs to share their collections, due to their fear of theft, and emphasizes the joyous scene of story-telling that is a constant and reassuring part of everyday life' for Wiradjuri people (Bamblett 2014: 77). Such attitudes express tensions within communities, as well as commonalities, and the status of photographs as often people's 'most treasured material possession'. In response, Bamblett developed a number of strategies for looking at these precious images that were designed to create trust, such as ensuring credit for ownership and a process of rapid copying and return. These tactics were based upon his personal relationships through kinship and community membership, as well as by establishing his good intentions and ethical approach through demonstration and ongoing relationships and informed consent. Bamblett concludes that 'The most enjoyable part of having this large collection is that it encourages people to gather at my home and talk about the past' (2014: 10).

These practices instantiate recent intellectual shifts in ways of seeing photographs, as a renewed interest has emerged in their diverse cultural uses. Where interpretation once focused on the meaning contained with the frame, as representation, over the last decade much scholarly analysis has explored the role of photographs as social actors within distributed networks of people and things that make up the social (e.g. Latour 2005, Gell 1998). This shift is sometimes glossed as a shift from what images mean to what they $d o$.

These interpretive shifts have intersected with Indigenous demands for restitution and return of cultural heritage, signaling a shift to acknowledge Indigenous rights in a wide range of material and intangible culture, and by extension photographs (Green and Gordon 2010, The Australian Institute for Aboriginal and Torres Strait Islander Studies 2015). Many cultural institutions across Australia and overseas now house large collections of photographs documenting Aboriginal lives and history. Since the 1970s, a growing international literature (e.g. Vokes 2012, Peers and Brown 2006, Edwards and Hart 2004, Brown and Peers 2003) has examined the process and effects of returning photographs to source communities.

\section{STOLEN GENERATIONS}


For many Aboriginal people, old photographs may be used to help re-connect family and connections to place torn apart by official assimilation policies known now as the Stolen Generations (Read 2006). The findings of a National Inquiry into the separation of Aboriginal and Torres Strait Islander children from their families (Australian Human Rights Commission 1997) revealed that the impact of these policies had left very few families untouched by their devastating effects, still felt painfully in the present in the form of broken family ties, sad childhood memories, and persisting anger and grief. In this context, many Aboriginal individuals and communities eagerly seek to reclaim photographs of relatives and ancestors lost through these historical processes, and explain the importance of recovering such images in their quest to re-connect with family and place (e.g. Briggs et al 2010). As Shauna Bostock-Smith's account of discovering her Great-Great Grand-Aunt's photo through a television documentary suggests, this is an emotional but often healing process. The documentary explored Australia's most famous nineteenth-century photographer John William Lindt, whose acclaimed 1872-1873 series Australian Aboriginals comprised portraits of Gumbaynggirr and Bandjalung peoples of the lower Clarence River (Grafton Regional Art Gallery 2005, Orchard 1999). Bostock-Smith (2014: 60) writes, that she 'gasped aloud' when she heard that Lindt's well-known image of 'Mary Ann of Ulmarra' (fig 17.4) was identified as Mary Ann Cowan, because:

I have been researching my family history for the last few years, and I knew that Mary Ann Cowan was my Great-Great Grand-Aunt. This exciting news had such a profound effect on me. It is as though this lovely photograph taken last century has spiritually reached through time and altered my perception of her today. She has now magically transformed from being an abstract entity.... a name on her marriage and death certificates, into a real life, flesh and blood, beautiful young woman.

The image brought to life her years of family research, and embodied a physical link with her ancestor that became the occasion to build further family connections, and to re-visit traditional country with relatives

Such stories exemplify the way that the photographic archive has been plundered, reassembled, and cross-pollinated by Aboriginal artists who challenge its colonial meanings. Through seemingly simple techniques of re-contextualization - over-writing, inscription, layering, enlargement, and re-surfacing - the historical image may be literally transformed. Wiradjuri artist Brook Andrew for example has deliberately attacked a legacy of invisible violence by retrieving 
photographs that bear traces of colonial trauma from the archive as evidence for the forgotten or concealed tragedies of dispossession. While he is careful to respect the distinction between these disturbing historical images and traditionally restricted secret-sacred subjects, Andrew (2007: 6) argues that 'they should be brought into the light, aroused in the public domain'. In his 2007 series Gun Metal Grey, the violence of colonialism is evoked by returning us to moments of fear or effacement; gleaming silver shrouds his subjects, like the woman of 'Ngalan' (Light), softening and reversing the colonial photographer's distancing gaze. Using deceptively simple techniques of enlargement and metallic foil coating, these overlooked fragments of evidence become 'unmanageable', swelling out from the archive, beyond our control.

Another strategy responds tangentially to the archive, producing new, Aboriginal-authored images. Some choose to re-create or re-imagine extant historical photographs - and even to cast themselves as reimagined subjects or heroes and heroines (e.g. Parsley 2011, Butler 2008: 1). One such engagement with the colonial archive is Christian Thompson's 2012 series We bury our own, in which he has responded to the collection held by the Pitt Rivers Museum at Oxford University, where he was a postgraduate student. We bury our own deploys Thompson's trademark self-portraits to displace the historical markers of identity central to colonial photography - especially the anthropometric mug shot. Here he is the photographer who chooses how to see the Indigenous subject.

Christopher Morton, Senior Curator of Photography at the Pitt Rivers Museum uses Thompson's own phrase, 'spiritual repatriation', to refer to a process of engaging with these images' colonial heritage in imaginative and allusive ways (Morton 2012). However, instead of returning the bodies of war victims, as originally denoted by the term 'repatriation', or even the original photo-object, Thompson creates an emotional, affective tie with the archive. During the nineteenth century, Indigenous bodies were in a sense captured by photographs that sought to reduce their humanity to an essential corporeal truth. Thompson, by contrast, shows us new forms of a cosmopolitan, hybrid Indigenous identity that transcends this literal return. The beauty, clarity and formality of these portraits convey a sacred process of acknowledgment of ancestral forces with great dignity and emotion.

\section{TRANSFORMING TINDALE}

Another recent landmark that has reclaimed the archive was the 2012 exhibition Transforming Tindale, hosted by the State Library of Queensland, curated by Michael Aird and based on the work of Vernon Ah Kee. Ah Kee is an artist from North Queensland, and a founding member of the Brisbane-based proppaNOW artists collective (Jones 2010, Ah Kee 2009). This project drew upon 
genealogical information and photographs amassed by anthropologists Norman Tindale and Joseph Birdsell in 1938, across several Queensland Aboriginal communities. Tindale and Birdsell studied Aboriginal 'hybrids', seeking to classify Aboriginal people into racial types. Together they undertook anthropological surveys in 1938-39 and again in 1952-54 on Aboriginal missions across Australia. After World War II Birdsell and Tindale abandoned their framework of racial classification in favour of population dynamics, and both, toward the end of their careers, became supporters of Aboriginal self-determination and the land-rights movement. Nonetheless, their substantial mission collections were made within a framework of racial classification, and they collected anatomical measurements and took standardized photographs as records of the physical form of the Aboriginal residents. It was not always a pleasant experience for the Aboriginal people involved, as Tauto Sansbury remembered (Roberts et al 2014).

However, the photographs have now taken on new dimensions. Artist Vernon Ah Kee had first encountered these photographs when he was young because his grandmother had carried some around in her purse (Barkley 2009). He discovered many years later that the originals contained much more detail than the cropped 'mugshots' she had owned. He drew large-scale charcoal portraits of his relatives based on the photos, in the process also learning about his greatgrandparents. Transforming Tindale comprised large format photographic prints placed in conversation with Ah Kee's drawings.

The exhibition was based on extensive discussion with the relatives of the photographic subjects, and the process leading up to this exhibition is inseparable from its final form, fulfilling the goal of re-connecting relatives with these photos, as well as the genealogies and field-notes Tindale collected. Like other Aboriginal communities across south-western Australia, where colonialism hit first and perhaps hardest, such links may be re-forged with the aid of photographs (e.g. Macdonald 2003). Just as important, as Heather Goodall (2006: 65) has noted of Brewarrina in north-western NSW where Tindale worked in 1938, '[i]t is not only traditional or even biological kinship which has generated the most complex and active readings, it has been the historical and lived experiences which these people had shared and which continue to link their descendants.' This is an emotional and often painful journey that forces descendants to confront the oppression of the past. Curator Michael Aird suggests that:

The Transforming Tindale exhibition was about the journey that Aboriginal people have been through to discover and connect with these images. As Vernon would always say 'the name Tindale might be in the title of the exhibition, but it is not about Tindale'. Instead it was all 
about a set of photos that Tindale played a part in producing and how people today relate to those photos. ${ }^{3}$

As well as exhibitions and publications, many projects have established digital points of contact between communities and archives. The much-loved Ara Iritija Project, for example, officially commenced in 1994 to repatriate 'lost' material for Anangu (Ngaanyatjarra, Pitjantjatjara and Yankunytjatjara people) of Central Australia. Meaning 'stories from a long time ago' in the language of Anangu, this digital archive makes available hundreds of thousands of historical and cultural items to the Aboriginal community. ${ }^{4}$

Similarly, but working from European collections back to their source communities, the Returning Photos: Australian Aboriginal Photos from European Collections project has since 2011 worked with four European museums - the University of Oxford's Pitt Rivers Museum, the Cambridge University Museum of Archaeology and Anthropology, the Musée de Quai Branly in Paris and the Nationaal Museum van Wereldculturen (National Museum of World Cultures) in Leiden, Netherlands - to historicise the photographs and return them to Indigenous descendants. ${ }^{5}$ Such projects aim for Aboriginal management of these historical archives, and return to their communities.

\section{CONCLUSION}

In Australia, the tumultuous final decades of the twentieth century witnessed a radical transformation of settler-Aboriginal relations as mainstream society began to acknowledge Indigenous experience and revise ideas of national identity: landmarks such as the 1988 Bicentenary, and the 1997 inquiry into the official assimilation policies now known as the Stolen Generations may be seen as the result of the long Aboriginal struggle for rights, in which photography played a vital role. Today Aboriginal people give photography a range of crucial meanings in documenting family, re-connecting broken links of kinship and history, making art, and telling the truth of an Indigenous history excised from the national story.

Photos help constitute Indigenous memory by revealing unknown ancestors lost during the displacements of colonialism, and substantiating Indigenous stories and experiences formerly hidden from view. In southern Australia, first invaded and longest settled by white colonists, colonial images have also assumed powerful new meanings in the context of colonial dispossession and loss. For Aboriginal artists, photographic archives offer a rich source of history, and a means 
to explore many issues that remain in the present. Archival images are tangible and powerful relics that provide a link with the past, and bring it concretely into our time. This is the power of photographs: to address absence, to re-connect relatives with each other and to Country, and to heal: as Wiradjuri scholar Lawrence Bamblett argues (2014: 99 photos link people in the present, as well as connecting them to places and the past; they 'fit into the joyful scene of people telling stories'. The history of broken families, and the dispossession and control of Aboriginal people remain contested, and often absent, from national stories, but these silences are filled by the solidity and presence of people recorded in photographic portraits.

\section{REFERENCES}

Ah Kee, V. and Institute of Modern Art (2009), Borninthisskin: Vernon Ab Kee, Brisbane: Institute of Modern Art.

Aird, M. (2003), 'Growing Up With Aborigines', in C. Pinney and N. Peterson (eds), Photography's Other Histories, 23-38, Durham: Duke University Press.

Aird, M. (2014), 'Aboriginal people and four early Brisbane photographers', in J. Lydon (ed), Calling the Shots: Aboriginal Photographies, 133-54, Canberra: Aboriginal Studies Press.

Andrew, B. (2007), 'Come into the light', in The Island Catalogue, Cambridge: Museum of Archaeology and Anthropology.

Anonymous (1848), 'Review of W Westgarth, Australia Felix. Historical and descriptive account of Port Phillip”, The Sydney Morning Herald, 15 June: 2.

Anonymous (1862) 'The Interesting Couple', Illustrated Melbourne Post, 5 July: 2.

Anonymous (1876), Argus (Melbourne), 1 September: 7.

Australian Human Rights Commission (1997), Bringing Them Home Report of the National Inquiry into the Separation of Aboriginal and Torres Strait Islander Children from Their Families, [Human Rights and Equal Opportunity Commission], Sydney.

Australian Institute for Aboriginal and Torres Strait Islander Studies (2015), Guidelines for the Ethical Publishing of Aboriginal and Torres Strait Islander authors and research from those communities, Canberra: Aboriginal Studies Press.

Attenbrow, V. (2002), Sydney's Aboriginal Past: Investigating the Archaeological and Historical records, Sydney: UNSW Press.

Ballantyne, T. (2012), Webs of Empire: Locating New Zealand's Colonial Past, Wellington: Bridget Williams Books. 
Bamblett, L. (2014), 'Picture Who We Are: Representations of Identity and the Appropriation of Photographs into a Wiradjuri Oral History Tradition', in J. Lydon (ed), Calling the Shots: Aboriginal Photographies, 76-100, Canberra: Aboriginal Studies Press.

Barkley, G. (2009), 'Vernon Ah Kee', in Borninthisskin: Vernon Ah Kee, 21-22, Brisbane: Institute of Modern Art.

Barnett, M. (2011), Empire of Humanity: A History of Humanitarianism, Ithaca: Cornell.

Becker, L. (1857), 'The nest, egg and young of the lyrebird (menura superba)', Transactions of the Philosophical Institute of Victoria, 1: 153-4.

Berkhofer, R. (1978), The White Man's Indian: Images of the American Indian from Columbus to the Present, New York: Vintage.

Bostock-Smith, S. (2014), 'Connecting with the Cowans', in J. Lydon (ed), Calling the Shots: Aboriginal Photographies, 61-65, Canberra: Aboriginal Studies Press.

Briggs, M., J. Lydon and M. Say (2010), 'Collaborating: Photographs of Koories in the State Library of Victoria ', La Trobe Journal, 85: 106-24.

Brown, A.K. and L. Peers, eds. (2003), Museums and Source Communities: A Routledge Reader, New York: Routledge.

Butler, R. (2008), 'Margaret Preston and the history wars', in Australian graffiti (catalogue), Melbourne: Gallery Gabrielle Pizzi.

Carey, J. and J. Lydon, eds. (2014), Indigenous Networks: Mobility, Connections and Exchange, New York and London: Routledge.

Chakrabarty, D. (2000), Provincializing Europe: Postcolonial Thought and Historical Difference, Princeton and Oxford: Princeton University Press.

Coleman, D. (2005), Romantic Colonization and British Slavery, Cambridge: Cambridge University Press.

Cooper, F. and A. L. Stoler, eds. (1997) Tensions of Empire: Colonial Cultures in a Bourgeois World, Los Angeles: University of California Press.

Croft, B. L. (1997), 'Laying Ghosts to Rest', in C. Cooper and A. Harris, Portraits of Oceania, 15-21, Sydney: Art Gallery of New South Wales.

Cunningham, P. (1827), Two Years in New South W ales, London: Henry Colburn.

Driessens, J. (2003), 'Relating to Photographs', in C. Pinney and N. Peterson (eds), Photography's Other Histories, 17-22, Durham: Duke University Press.

Edwards, E. (1992), Anthropology and Photography, 1860-1920, New Haven: Yale University Press.

Edwards, E. and J. Hart, eds. (2004), Photographs, Objects, Histories: On the Materiality of Images, New York: Routledge.

Ennis, H. (2007), Photography and Australia, London: Reaktion Books. 
Fanon, F. (1961), The Wretched of the Earth, New York: Grove Press.

Fitzmaurice, A. (2007), 'The genealogy of Terra Nullius', Australian

Historical Studies, 38 (129): 1-15.

Gell, A. (1998), Art and Agency: An Anthropological Theory, Oxford: Oxford University Press.

Giglioli, E. (1875), Viaggio intorno al globo della r. pirocorvetta italiana Magenta negli anni 1865-66-67-68

(V oyage around the globe on the Magenta), Milan: V Maisner e Compagnia.

Goodall, H. (2006), 'Karroo- Mates: Communities Reclaim their Images', Aboriginal History, 30: 48-66.

Grafton Regional Gallery (2005), The John William Lindt Collection, Grafton: Grafton Regional Gallery.

Green, M. and P. Gordon (2010), 'Repatriation: Australian Perspectives', in J. Lydon and U. Rizvi (eds), Handbook of Postcolonial Archaeology, World Archaeological Congress, 257-65, London: Left Coast Press.

Hall, C. (2002), Civilising Subjects: Metropole and Colony in the English Imagination 1830-1867, Cambridge: Polity.

Hartmann, W., J. Silvester and P. Hayes (1998), The Colonising Camera: Photographs in the Making of Namibian History, Cape Town: University of Cape Town Press.

Hughes, K. and E. Trevorrow (2014), 'It's that reflection': Photography as Recuperative Practice, a Ngarrindjeri, in J. Lydon (ed), Calling the Shots: Aboriginal Photographies, 175-204, Canberra: Aboriginal Studies Press.

Jones, G. (2010), 'Vernon Ah Kee: Sovereign Warrior’ Artlink, 30: 46-53.

Jones, P. (2011), Images of the interior, Kent Town, South Australia: Wakefield Press.

Kean, J. (forthcoming), Empirical Eye: Scientific Illustration in Colonial Australia, Melbourne: Museum Victoria.

Macdonald, G. (2003), 'Photos in Wiradjuri biscuit tins: negotiating relatedness and validating lives', Oceania, 73 (4): 225-42.

Langton, M. \& Australian Film Commission (1993), 'Well, I heard it on the radio and I saw it on the television': an essay for the Australian Film Commission on the politics and aesthetics of filmmaking by and about Aboriginal people and things, Sydney: Australian Film Commission.

Latour, B. (2005), Reassembling the Social: An Introduction to Actor-Network-Theory, Oxford: Oxford University Press.

Lydon, J. (2005), Eye Contact: Photographing Indigenous Australians, Durham: Duke University Press.

Lydon, J. (2010), 'Return: The photographic archive and technologies of Indigenous memory', Photographies, 3 (2): 173-87.

Lydon, J. (2012), The Flash of Recognition: Photography and the Emergence of Indigenous Rights, Sydney: NewSouth Books. 
Lydon, J., ed. (2014a), Calling the Shots: Aboriginal Photographies, Canberra: Aboriginal Studies Press.

Lydon, J. (2014b) 'Introduction', in J. Lydon (ed), Calling the Shots: Aboriginal Photographies, 1-18, Canberra: Aboriginal Studies Press.

Lydon, J. (2016), Photography, Humanitarianism, Empire, London: Bloomsbury.

Mitchell, J. (2009), “'The galling yoke of slavery”: race and separation in colonial Port Phillip', Journal of Australian Studies, 33 (2): 125-37.

Morris, R. C. (2009), Photographies East: The Camera and Its Histories in East and Southeast Asia, Durham: Duke University Press.

Morton, C. (2012), 'Spiritual repatriation and the archive in Christian Thompson's We Bury Our Own', Christian Thompson: We Bury Our Own (exhibition catalogue), 13-15, Fitzroy: Gallery Gabrielle Pizzi.

Orchard, K. (1999), 'J. W. Lindt's Australian Aboriginals (1873-74)', History of Photography, 23 (2): 163 70.

Parsley, C. (2011), 'Christian Thompson and the art of indigeneity', Discipline 1 (1), http://discipline.net.au/Discipline/Issue_1_files/Connal\%20Parsley\%20-

\%20Christian\%20Thompson.pdf (accessed 24 December 2015).

Peers, L. and A. K. Brown with members of the Kainai Nation (2006), 'Pictures bring us messages': Sinaakssiilesi aohtsimaahpibkookiyaawa: photographs and histories from the Kainai Nation, Toronto: University of Toronto Press.

Pinney, C. (2003), 'Introduction: How the Other Half ...', in C. Pinney and N. Peterson (eds), Photography's Other Histories, 1-16, Durham: Duke University Press.

Pinney, C. and N. Peterson, eds. (2003), Photography's Other Histories, Durham: Duke University Press.

Poole, D. (1997), Vision, Race, and Modernity: A Visual Economy of the Andean Image World, Princeton and Oxford: Princeton University Press.

Read, P. (2006), The stolen generations: The removal of Aboriginal children in New South Wales 1883 to 1969, Sydney: New South Wales Department of Aboriginal affairs.

Ritter, D. (1996), "The "Rejection of terra nullius", in Mabo: A Critical Analysis, Sydney Law Review, 18 (1): 5-33.

Roberts, A., M. Fowler and T. Sansbury (2014), 'A report on the exhibition "Children, Boats and Hidden Histories": Crayon drawings by Aboriginal children at Point Pearce Mission (Burgiyana) (South Australia), 1939', Bulletin of the Australasian Institute for Maritime Archaeology, 38: 24-30.

Ryan, J. R. (2007), Picturing Empire: Photography and the Visualization of the British Empire, London: Reaktion Books.

Said, E. (1978), Orientalism, London: Penguin. 
Skinner, R. and A. Lester (2012), 'Humanitarianism and Empire: New Research Agendas', The Journal of Imperial and Commonwealth History, 40 (5): 729-47.

Solomon-Godeau, A. (1991), Photography at the Dock: Essays on Photographic History, Institutions, and Practices, Minneapolis: University of Minnesota Press.

Sprague, S. (2003 [1997]), 'Yoruba Photography: How the Yoruba See Themselves', in C. Pinney and N. Peterson (eds), Photography's Other Histories, 240-260, Durham: Duke University Press.

Tagg, J. (1993), The Burden of Representation: Essays of Photographies and Histories, Minneapolis: University Of Minnesota Press.

Taylor, P, ed. (1988), After 200 Years: Photographic Essays of Aboriginal and Islander Australia Today, Canberra: Australian Institute of Aboriginal Studies.

Thomas, N. (1994), Colonialism's Culture: Anthropology, Travel, and Government, Princeton and Oxford: Princeton University Press.

Vokes, R., ed. (2012), Photography in Africa: Ethnographic Perspectives, Woodbridge; Rochester: James Currey.

Westgarth, W. (1848), Australia Felix, or A Historical and descriptive account of the settlement of Port Phillip, New South W ales: including full particulars of the manners and customs of the Aboriginal natives ... Edinburgh: Oliver \& Boyd.

Willis, A. (1988), Picturing Australia: A History of Photography, Sydney: Angus and Robertson.

Wood, R. D. (2005), 'The voyage of Captain Lucas and the daguerreotype to Sydney', in A. Foucrier (ed), The French and the Pacific World, 17th-19th Centuries: Explorations, Migrations and Cultural Exchanges, 69-79, Aldershot, England, and Burlington, VT: Ashgate Publishing Ltd/Variorum.

\footnotetext{
${ }^{1}$ NSW Governor Bourke's Proclamation of 1835 is generally considered to mark the inception of the principle subsequently followed in law, and has often been referred to as the doctrine of terra nullius. However, since the mid-1990s, historians have shown that this term was not used during the nineteenth century. See for example, Ritter (1996).

${ }^{2}$ The Wurundjeri were the clan of Woi-wurrung language-speakers whose traditional country was first occupied by the settlement of Melbourne.

${ }^{3}$ Michael Aird, personal communication to the author, January 2015.

${ }^{4}$ http://www.irititja.com/about_ara_irititja/index.html (accessed 30 July 2016).

${ }^{5}$ https://ipp.arts.uwa.edu.au (accessed 30 July 2016).
} 